\title{
Old or Age Indeterminate Right Ventricular Myocardial Infarction by ECG Finding
}

National Cancer Institute

\section{Source}

National Cancer Institute. Old or Age Indeterminate Right Ventricular Myocardial

Infarction by ECG Finding. NCI Thesaurus. Code C102692.

An electrocardiographic finding, in the presence of an old or age indeterminate inferior wall myocardial infarction, of Q waves greater than or equal to $40 \mathrm{~ms}$ in duration in the right ventricular leads V4R through V6R. (CDISC) 